\title{
Editorial
}

\section{Interneonatal Intensive Care Unit Variation in Growth Rates and Feeding Practices in Healthy Moderately Premature Infants}

\section{Reese H. Clark, MD}

Journal of Perinatology (2005) 25, 437-439. doi:10.1038/sj.jp.7211288

In this month's Journal of Perinatology, Blackwell et al. (reference) describe the "Interneonatal Intensive Care Unit Variation in Growth Rates and Feeding Practices in Healthy Moderately Premature Infants".

Several large databases of information are available for the short- and long-term outcomes of prematurely born neonates ${ }^{1-3}$ and previous investigations have evaluated the perinatal and neonatal factors associated with poor outcomes; however, data on more mature, healthier neonates is lacking. The authors correctly note, "Care of the healthy but immature infant born between 30 and 35 weeks GA has received little attention in the last decade," and remind us that infants with birth weights of 1500 to $2500 \mathrm{~g}$ represented 7 to $8 \%$ of live births in 2002, and 35 to $50 \%$ of NICU admissions and bed days.

Failure to conduct research in any specific group of patients leads to uncertainty of "standard of a care" and promotes variation in practice. The degree of variation is readily apparent in outcomes, ${ }^{3,4}$ medication use, ${ }^{5,6}$ and nutritional support. ${ }^{7-9}$ This variation is not helpful or justifiable and screams for better prospective studies to define appropriate standard of care. The best way to improve care is through research that demonstrates both safety and efficacy. We have successfully carried this out in the past $^{10,11}$ and we can and should do this in the area of nourishing neonates.

In a recent review, we described the term, "extrauterine growth restriction," which refers to the concept that prematurely born neonates develop a severe nutritional deficit during the first weeks after birth. ${ }^{12}$ Despite some catch-up growth during the second month of hospitalization, many neonates go home undergrown. Their nutritional deficit affects not only their weight, but their length and head circumference as well.

Safely nourishing premature neonates is difficult, resulting in accrued nutrient deficits, which are greatest in neonates less than 30 weeks' estimated gestational age. However, as Blackwell et al.

Pediatrix Medical Group (R.H.C.), Sunrise, FL 33323-2843, USA.

Address correspondence and reprint requests to Reese Clark, Pediatrix Medical Group, Inc., 1301 Concord Terrace, Sunrise, FL 33323-2843, USA. (reference) clearly demonstrate, malnutrition is also a problem for more mature (30 to 35 weeks' estimated gestational age) neonates. A recent study suggests that postnatal malnutrition and growth restriction are inevitable, if we follow the current recommended dietary intakes. ${ }^{13}$

Failure to see daily weight gain and failure to thrive are late manifestations of malnutrition, while growth measurements (weight, length, and head circumference) are macroscopic measures of nutritional status. Energy deficiency, as well as micronutrient deficiency, can alter growth at a cellular and a systemic level before macroscopic measures are altered. In the brain, energy is needed for cell division and growth (e.g., neuronal growth), transport via the radial glial cells, and myelination. Malnourished neonates often experience immune deficiencies that reflect poor protein stores, which exacerbate an already immature immune system. In addition, nutrition may be therapeutic (reparative) for premature neonates by allowing more rapid adaptation to the extrauterine environment. To prevent growth failure and extrauterine growth restriction, we need to detect nutrient deficiencies early and act to correct them.

Early nutrition or failure thereof may program neonates for later morbidity. ${ }^{14-16}$ Critical periods of nutritional "exposures" prenatally and during the postnatal period appear to influence an individual's disease risks throughout life. ${ }^{17-20}$ In early life, poor growth may reset the potential for later growth. ${ }^{20-22}$ Postnatal growth lag is associated with neurological and sensory handicaps and poor school performance. Hack et al. ${ }^{23,24}$ showed that subnormal head size at 8 months of age was predictive of poorer verbal and performance IQ scores at eight years of age; lower scores for receptive language, speech, reading, mathematics, and spelling; and a higher incidence of hyperactivity. ${ }^{23,24}$ Population-based studies evaluating the effects of poor fetal growth support these observations. ${ }^{25-29}$

Blackwell and others have established that variation in dietary support accounted for a substantial proportion of variation in the growth of neonates cared for in different neonatal intensive care units. ${ }^{7,8}$ We (neonatologists, neonatal nurses, and nutritionists, and every other member of the health care team) can and should improve our nutritional care practices by carefully reviewing the recommendations from Blackwell et al. (reference). The patients studied were at very low risk for bowel complications. We cannot starve $100 \%$ of our infants and hide behind the defense that we are doing it to avoid necrotizing enterocolitis (NEC), since less than 3\% 
of neonates at $\geq 30$ weeks' estimated gestational age will develop NEC that requires treatment. ${ }^{30}$ Additionally, centers that nourish their neonates well do not have higher rates of $\mathrm{NEC}^{7}$ and most studies looking at more rapid advances of feedings have not shown an increased rate of NEC. ${ }^{31,32}$ This is particularly true in low-risk neonates.

The literature on our failure to translate new evidence into clinical practice and process change is well established. ${ }^{33}$ It plagues all areas of medicine. Yet, the simple truth is that one of the most important aspects of improvement is attending to the problem. This is the point of having growth charts in the offices of every pediatrician who offers care to children. It forces her/him to attend to her/his patients' nutritional needs. It is not sufficient to pay attention to calorie intake without demonstrating that the level of reported caloric support is leading to good growth (symmetric increases in weight, length, and head circumference).

While more and better evidence is needed to help guide best practices, this should not prevent neonatologists from using the clinical observations presented by Blackwell and others to improve their current practice. There is credible evidence that small safe changes in current practice can have a positive influence on growth. ${ }^{7,8}$ These include early administration of intravenous amino acids and lipids, minimal enteral nutrition, and supplemented formula and human milk. Simply recognizing the degree of growth failure by monitoring weight and focusing on the accruing deficit should encourage clinicians to increase nutritional support to enhance recovery growth.

\section{References}

1. Vohr BR, Allen M. Extreme prematurity — the continuing dilemma. N Engl J Med 2005;352(1):71-2.

2. Stoll BJ, Hansen NI, Adams-Chapman I, Fanaroff AA, Hintz SR, Vohr B, et al. Neurodevelopmental and growth impairment among extremely lowbirth-weight infants with neonatal infection. JAMA 2004;292(19):2357-65.

3. Horbar JD, Badger GJ, Lewit EM, Rogowski J, Shiono PH. Hospital and patient characteristics associated with variation in 28-day mortality rates for very low birth weight infants. Vermont 0xford Network. Pediatrics 1997;99(2):149-56.

4. Vohr BR, Wright LL, Dusick AM, Perritt R, Poole WK, Tyson JE, et al. Center differences and outcomes of extremely low birth weight infants. Pediatrics 2004;113(4):781-9.

5. Horbar JD, Carpenter JH, Buzas J, Soll RF, Suresh G, Bracken MB, et al. Timing of initial surfactant treatment for infants 23 to 29 weeks' gestation: is routine practice evidence based? Pediatrics 2004;113(6):1593-602.

6. Horbar JD, Carpenter JH, Buzas J, Soll RF, Suresh G, Bracken MB, et al. Collaborative quality improvement to promote evidence based surfactant for preterm infants: a cluster randomised trial. Br Med J 2004;329(7473):1004.

7. Bloom BT, Mulligan J, Arnold C, Ellis S, Moffitt S, Rivera A, et al. Improving growth of very low birth weight infants in the first 28 days. Pediatrics 2003;112(1 Part 1):8-14.
8. Olsen IE, Richardson DK, Schmid CH, Ausman LM, Dwyer JT. Intersite differences in weight growth velocity of extremely premature infants. Pediatrics 2002;110(6):1125-32.

9. Powers NG, Bloom B, Peabody J, Clark R. Site of care influences breastmilk feedings at NICU discharge. J Perinatol 2003;23(1):10-3.

10. Jobe AH. Pulmonary surfactant therapy. N Engl J Med 1993;328(12): 861-8.

11. Lucas A, Fewtrell MS, Morley R, Singhal A, Abbott RA, Isaacs E, et al. Randomized trial of nutrient-enriched formula versus standard formula for postdischarge preterm infants. Pediatrics 2001;108(3):703-11.

12. Clark RH, Wagner CL, Merritt RJ, Bloom BT, Neu J, Young TE, et al. Nutrition in the neonatal intensive care unit: how do we reduce the incidence of extrauterine growth restriction? J Perinatol 2003;23(4):337-44.

13. Embleton NE, Pang N, Cooke RJ. Postnatal malnutrition and growth retardation: an inevitable consequence of current recommendations in preterm infants? Pediatrics 2001;107(2):270-3.

14. Barker DJ. Fetal origins of cardiovascular disease. Ann Med 1999;31 (Suppl 1):3-6.

15. Barker DJ. The long-term outcome of retarded fetal growth. Schweiz Med Wochenschr 1999;129(5):189-96.

16. Bernstein IM, Horbar JD, Badger GJ, Ohlsson A, Golan A. Morbidity and mortality among very-low-birth-weight neonates with intrauterine growth restriction. The Vermont 0xford Network. Am J Obstet Gynecol 2000;182(1 Part 1):198-206

17. Singhal A, Farooqi IS, O'Rahilly S, Cole TJ, Fewtrell M, Lucas A. Early nutrition and leptin concentrations in later life. Am J Clin Nutr 2002;75(6):993-9.

18. Singhal A, Cole TJ, Lucas A. Early nutrition in preterm infants and later blood pressure: two cohorts after randomised trials. Lancet 2001;357(9254):413-9.

19. Fewtrell MS, Cole TJ, Bishop NJ, Lucas A. Neonatal factors predicting childhood height in preterm infants: evidence for a persisting effect of early metabolic bone disease? J Pediatr 2000;137(5):668-73.

20. Lucas A. Programming by early nutrition: an experimental approach. J Nutr 1998;128(2 Suppl):401S-6S.

21. Morley R, Lucas A. Influence of early diet on outcome in preterm infants. Acta Paediatr Suppl 1994;405:123-6.

22. Morley R, Lucas A. Randomized diet in the neonatal period and growth performance until 7.5-8 y of age in preterm children. Am J Clin Nutr 2000;71(3):822-8.

23. Hack M, Breslau N, Weissman B, Aram D, Klein N, Borawski E. Effect of very low birth weight and subnormal head size on cognitive abilities at school age. N Engl J Med 1991;325(4):231-7.

24. Hack M, Taylor HG, Klein N, Eiben R, Schatschneider C, Mercuri-Minich N. School-age outcomes in children with birth weights under $750 \mathrm{~g}$. N Engl J Med 1994;331(12):753-9.

25. Jefferis BJ, Power C, Hertzman C. Birth weight, childhood socioeconomic environment, and cognitive development in the 1958 British birth cohort study. Br Med J 2002;325(7359):305.

26. Matte TD, Bresnahan M, Begg MD, Susser E. Influence of variation in birth weight within normal range and within sibships on IQ at age 7 years: cohort study. Br Med J 2001;323(7308):310-4.

27. Richards M, Hardy R, Kuh D, Wadsworth ME. Birth weight and cognitive function in the British 1946 birth cohort: longitudinal population based study. Br Med J 2001;322(7280):199-203. 
28. Richards M, Hardy R, Kuh D, Wadsworth ME. Birthweight, postnatal growth and cognitive function in a national UK birth cohort. Int $\mathrm{J}$ Epidemiol 2002;31(2):342-8

29. Shenkin SD, Starr JM, Pattie A, Rush MA, Whalley LJ, Deary IJ. Birth weight and cognitive function at age 11 years: the Scottish Mental Survey 1932 Arch Dis Child 2001;85(3):189-96.

30. Guthrie SO, Gordon PV, Thomas V, Thorp JA, Peabody J, Clark RH. Necrotizing enterocolitis among neonates in the United States. J Perinatol 2003;23(4):278-85.
31. Kennedy KA, Tyson JE, Chamnanvanakij S. Rapid versus slow rate of advancement of feedings for promoting growth and preventing necrotizing enterocolitis in parenterally fed low-birth-weight infants. Cochrane Database Syst Rev 2000;(2):CD001241.

32. Kennedy KA, Tyson JE, Chamnanvanikij S. Early versus delayed initiation of progressive enteral feedings for parenterally fed low birth weight or preterm infants. Cochrane Database Syst Rev 2000;(2):CD001970.

33. Lenfant $\mathrm{C}$. Clinical research to clinical practice - lost in translation? $\mathrm{N}$ Engl J Med 2003;349(9):868-74. 